\title{
Cardiovascular magnetic resonance in familial amyloidosis
}

\author{
Maria A Espinoza Barillas \\ From 19th Annual SCMR Scientific Sessions \\ Los Angeles, CA, USA. 27-30 January 2016
}

\section{Background}

Endomyocardial biopsy is considered the gold standard tool, but it is an invasive method, with low sensitivity and specificity, the echocardiographic diagnosis is difficult. MRI has recently emerged as a noninvasive technique that provides morphological, functional and tissue characterization information in evaluating this condition.

\section{Methods}

Our objective was to identify morphological and functional findings of familial amyloidosis in Cardiovascular Magnetic Resonance and compare this findings between asymptomatic patients and those with cardiovascular symptoms. Cardiovascular Magnetic Resonance was performed in 19 patients with familiar amyloidosis, 9 of them with cardiovascular symptoms, the remaining 10 were asymptomatic. The diagnosis of amyloidosis was previously done by periumbilical fat biopsy and genetic studies.

\section{Results}

The LVEF was preserved in $74 \%$ of the cases but $90 \%$ had alterations in global contractility. The atrioventricular valves were thickened in all patients. The right ventricle and atria were affected in $26 \%$ and $47 \%$ respectively. The most frequent pattern of enhancement in late gadolinium phase was suboptimal myocardial nulling (36\%), followed by global transmural heterogeneous pattern.

\section{Conclusions}

Suboptimal myocardial nulling was the most common pattern of late gadolinium enhancement found in this study, its present even in the absence of morphological changes.

\footnotetext{
Radiology, Instituto Nacional De Ciencias Medicas Y Nutricion Salvador Zubiran, Mexico DF, Nicaragua
} 

and take full advantage of:

- Convenient online submission

- Thorough peer review

- No space constraints or color figure charges

- Immediate publication on acceptance

- Inclusion in PubMed, CAS, Scopus and Google Scholar

- Research which is freely available for redistribution 